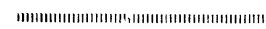

論文 ORIGINAL PAPERS

\title{
疲労き裂先端近傍の転位組織の直接観察 (鉄)*
}

\author{
粟 谷 丈 夫** 片 桐一而宗** 白 石 哲 郎***
}

\begin{abstract}
Direct Observations of Substructures Induced near Fatigue
Crack Tips in Bulk Specimens of Iron
\end{abstract}

by

\author{
Jobu Awatani, Kazumune KatAGIRI \\ and Tetsuro SHIRAISHI \\ (Institute of Scientific and Industrial Research, Osaka University, Suita)
}

In this paper, the method of jet-electropolishing is described, by which few-microns thick foil specimens containing a considerably sharp crack can be prepared from bulk fatigued-specimens of iron, and the substructures in the vicinity of the cracks observed through a $2000 \mathrm{kV}$ electron microscope are shown. They are; (1) a fine cell structure formed in the areas near the crack sides, and (2) dislocation tangles of extremely high density developed around the crack tips, where the cell structure is indistinguishable. In the present study, many cracks were observed crossing cells, but few propagated along cell-boundaries. Neither microcracks nor voids were observed ahead of the tips of the cracks inside bulk specimens.

The results obtained here suggest that, as a crack passes, the tangled dislocations ahead of the crack tip disappear or are rearranged to form the boundaries of cells, and, therefore, the propagation of fatigue cracks (Stage II) occurs in a work-hardened area, accompanied by plastic relaxation.

(Received June 11, 1975)

\section{1 緒言}

疲労き裂の伝ぱ機構を明らかにするためには，き裂 先端近傍に形成された転位組織の情報を知ることが重 要な事柄の一つと考兄られる．これまでき裂先端近傍 の組織観察には多くの努力が払われ，かなりの成果が あげられた。しかし，それらは薄膜の疲労現象を取り 扱ったものであり，命ルク材についてのこの方面の研 究はきわめて少なく，まだ充分な知見は得られていな いようである.これは, 通常内部組織の観察は電解研 摩で作られた薄膜試料に対して行なわれているが，バ ルク材からき裂をそのまま保有した薄膜の作製は技術 的にほとんど不可能とされていたためであろらと思わ れる.このたび筆者らの研究室に打いてジェット式電 解研摩で, き裂の部分をそれほど侵さない研摩条件の あることがわかった. この方法で作製した薄膜は数ミ クロンのかなり厚いものであったけれども, 超高電圧

* 原稿受理 昭和50年 6 月 11 日

** 正会員大阪大学産業科学研究所吹田市山田上:

*** 学生会員 大阪大学産業科学研究所 吹田市山田上
電子顕微鏡 $(2000 \mathrm{kV})$ により，その内部組織を充分 観察することができた.

本文は, これらジェット式電解研摩法の概略および き裂先端近傍の組織観察の結果について述べたもので ある・

$$
2 \text { 実験 }
$$

\section{$2 \cdot 1$ 試験片}

材料には Table I に示した化学成分の鉄を用いた。 まず，12申の丸棒素材を冷間圧延により板状にし，そ れから Fig.1 に示すよらな形状の試験片を作った。

これらは 0.25 および $0.30 \mathrm{~mm}$ の厚さであったが，900

${ }^{\circ} \mathrm{C}, 1 \mathrm{hr}$ の真空焼なまし後の平均粒径は約 $60 \mu$ であ ったのでここの程度の厚さでも充分バルク材と見なし

Table I. Chemical composition of iron used (wt\%).

\begin{tabular}{c|c|c|c|c|c|c|c}
\hline $\mathrm{Fe}$ & $\mathrm{C}$ & $\mathrm{Si}$ & $\mathrm{Mn}$ & $\mathrm{Cu}$ & $\mathrm{P}$ & $\mathrm{S}$ \\
\hline 99.66 & 001 & 0.01 & 028 & 002 & 0009 & 0.01 \\
\hline
\end{tabular}




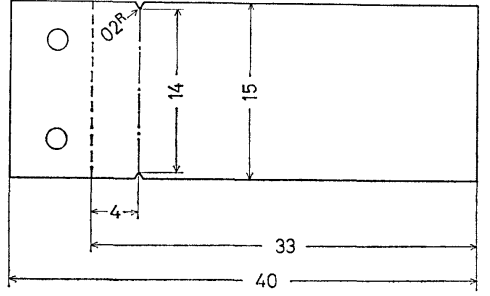

Fig. 1. Fatigue specimen.

らるものと思われた。試験片はすでに報告した自由振 動型の平面曲げ疲労試験によって行ない，観察は主に 切欠き底から 1.5 2.0 mm まで成長したき裂の先端 近傍について行なった。 この試験方法では, 試験片に 作用する公称応力の正確な算定は困難であるが，試料 表面のき裂の長さから，き裂進展速度を知ることがで きる．試験片の振動振幅を一定に保ったとき，上記の き裂長さに拈ける進展速度は $0.010 \sim 0.015 \mu /$ cycle 程度であった．また，試験中，共振周波数を調節しな ければ，き裂の進展とともに振幅は次第に低下し，き 裂は進展しなくなる、このよらな停留き裂についても 観察を行なった.

\section{$2 \cdot 2$ 薄膜作製}

通常の電解研摩法ではき裂近傍が優先的に研摩され るので，鋭いき裂を含む薄膜試料の作製は技術的にほ とんぞ不可能とされてきた。しかし，ジェット式電解 研摩に沶いて研摩速度をある程度速くすると，き裂は それほど侵されずに, 試料は数ミクロン程度まで薄く なることがわかった。この現象の詳細なことは明らか でないが，研摩速度が速く，電解液がき裂内部深くへ 侵入する余裕がないためでないかと思われる。このよ らな条件での研摩量と時間の関係をFig. 2 に示した.

実際に必要な薄膜の作製は次のような要領で行なっ た.上向きにしたジェット・ノズルを金属顕微鏡試料 台の下に，その光軸と一致するように組み込も. 試験

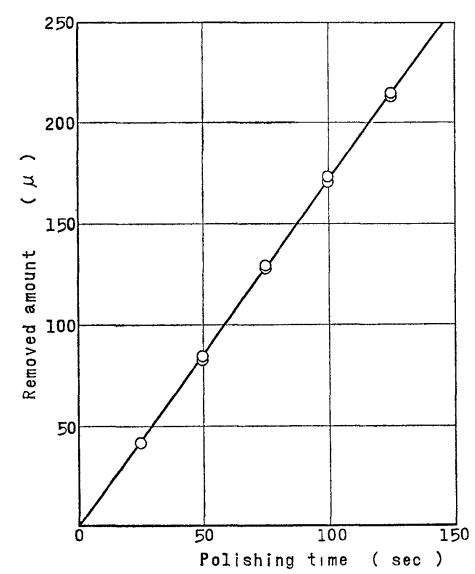

Fig. 2. The relation between removed amount and polishing time.
片の乗っている顕微鏡試料台を移動して目的とする場 所（き裂の先端）を，研摩によっでありれる小孔の 予想位置近くに置くここよらな状態で試験片の裏面 から適当な深さまで研摩したのち，試験片を裏返し，

まえと反対面の研摩を行なう，後段の研摩に和いては 絶えず顕微鏡観察を行ない，所定の位置に小孔があき， これが成長してその周辺がき裂の先端に近づいた瞬間 をとらえて研摩操作を中止する. このような方法によ り試料表面より任意の深さの場所からき裂を含む薄膜 を作ることができる。

研摩の良否を左右する種々の条件の中, 電流密度の 影響が最も大きいよらに思われたが，ここで使用した 他の条件とともにその一例を Table II に示した.

Fig. 3 はこの装置の説明図であり,Fig. 4 は試験片表 面より $40 \mu$ の場所から作製した薄膜試料の，き裂とそ の先端近傍にあけられた小孔を示している.

前述のように，これら薄膜試料の厚さは数ミクロン 程度のものが多く, 通常の $100 \mathrm{kV}$ 電子顕微鏡では, その内部組織を観察することはできなかったので，超

Table II. Conditions of electropolishing.

\begin{tabular}{c|c|c|c|c}
\hline Electrolyte & $\begin{array}{c}\text { Voltage } \\
(\mathrm{V})\end{array}$ & $\begin{array}{c}\text { Current } \\
\text { density } \\
\left(\mathrm{A} / \mathrm{cm}^{2}\right)\end{array}$ & $\begin{array}{c}\text { Tem- } \\
\text { perature } \\
\left({ }^{\circ} \mathrm{C}\right)\end{array}$ & $\begin{array}{c}\text { Distance bet. } \\
\text { nozzle and } \\
\text { specimen } \\
(\mathrm{mm})\end{array}$ \\
\hline $\begin{array}{c}20 \% \text { perchloric } \\
\text { acid }\end{array}$ & $70-80$ & 4.5 & 20 & 1.5 \\
\hline \begin{tabular}{c}
$80 \%$ ethanol \\
\hline
\end{tabular} & & & \\
\hline
\end{tabular}

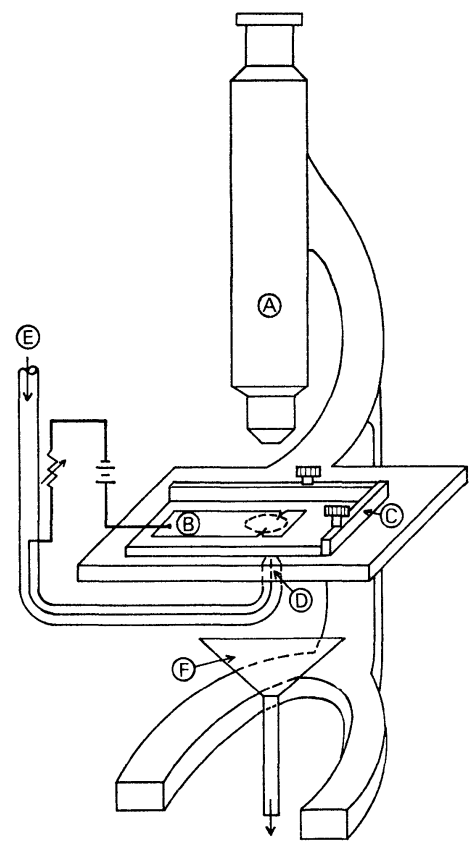

Fig. 3. Schematic diagram of jet-electropolishing apparatus combined with microscope: A, tube of microscope; $B$, fatigue specimen; C, cross stage; $D$, nozzle of jet ; $E$, inlet of electrolyte: F, funnel. 


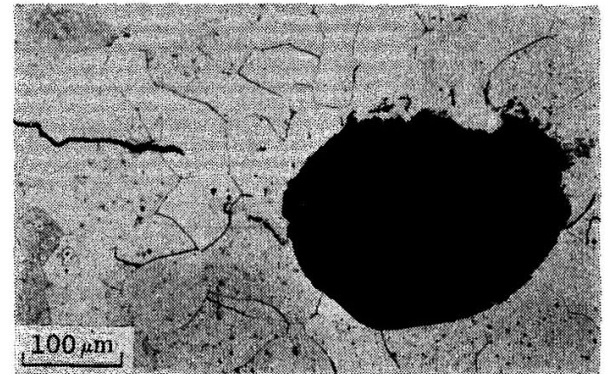

Fig. 4. The appearance of crack tip, the vicinity of which is perforated by jet-electropolishing.

高電王電子顕微鏡（公称電圧 $3000 \mathrm{kV}$, 測 定電圧 $2000 \mathrm{kV}$ ) を使用した。

\section{3 観察結果と考察}

小寺沢は試験片表面から約 $30 \mu$ までの層に拈外る疲 労き裂の挙動は，それより内部に括けるものと著しく 異なることを明らかにしているので，以下の観察はそ れよりも内部（試料表面より $40 \mu$ K和ける層）でのき 裂について行なった。

Fig. 5 (a)扰よび(b)はさ裂側面仗形成された転位組織 の代表的なもので, 明りょうなセル構造を示している. セル内部の見掛忷上の転位密度は比校的低く，七ルの 寸法はき裂の側面からの距離とともに次第に大きくな っているよらに思われる．き裂の側面に形成される組 織のこのような特長は，銅について観察した Klesnil と Lukas 拈よび Purcell と Weertman らのものと

よく似ている.

これに対し，き裂先端近傍には Fig. 6 (a)拈よび(b) に示すような転位組織が観察された。き裂先端からか

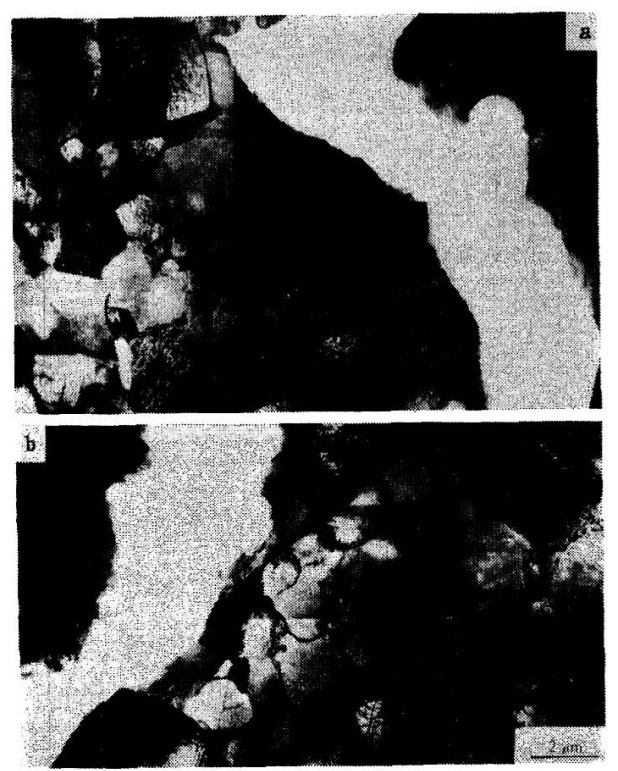

Fig. 5. Dislocation structures in the vicinity of crack side.
なり離れた領域では明りょらなセル構造になっている けれども，直接先端近傍には，きわめて密度の高いか らみ合った転位林が形成され，七ル構造はこれらの転 位林炕っててスクされたようと无る.Fig.6では、 からみ合った転位線は集まっで゙ンド状に及兄ている が，これはコンターのところで転位線が最も強いコン トラストを示すきためであるうと思われる。しかし傾斜 位置での試料観察からこのような高密度転位林がき 裂先端近傍に一様に分布していることが確認された。

Fig. 7 (a)は前述の停留き裂先端近傍の組織である. 進行き裂上停留き裂とでは, それら先端近傍に形成さ れる組織の特長に大きな差異は認められないが，停留 き裂では高密度転位林の形成される領域は進行き裂の 場合よりかなり狭いようである。この実験中，たなた ま，結晶粒界に括いて著しく進行方向を変觉たき裂を 観察した.このようなき裂は応力軸て対して直角では なく，したがってき裂作用する応力む小さくなって いるもの之思われる.もちろん，これは例外的のあの であったが，そのき裂先端の組織が転位のからみ合い を始める初期段階を暗示し, 興味あるものと思われた のでここに示した (Fig.7 (b)).

疲学き裂は七儿壁に沿って進展するといら説がある が, この研究ではこのよらなき裂は活とんぞ観察され なかった。むしろ，七ルを分割しながら進行している ものが多く観察された. Fig. 8 (a)拈よび(b)はその例で ある、しかしながら，このような観察結果はき裂の通 路と，その通過後に回復した内部組織 (Figs. 5 と 6 参 照) との関係を示していることになるのでこれから はき裂伝ば機構についての充分な知見は得がたいよう に思初る。

また, 本研究では, 試料表面からほぼ $30 \mu$ 以上内部 でのき裂 (Stage II) の先端近傍に微小き裂やボイド は観察されなかった. 試料表面近辺にこれらが観察さ れてあ，关れは表面層に特有な現象であるらと思われ た.

以上これらの観察結果から次のことがわかる. (1) き裂の先端近傍は, 高密度のからみ合った転位林のた めに，非常に強い加工硬化をらけている．そしてこの 領域は一サイクル中のき裂の進展距離よりるかなり大 きい（2)き裂が通過するとき，これら転位林の消失ま たは再配列によって，かなりの塑性緩和が起こってい る (Figs. 5 および 7 参照).この芙験で観察したき裂 はかなり低い進展速度での Stage II cracks であった が，さらに高い進展速度に達したき裂についても，そ の先端の組織に本質的な違いはないのではないかと考 えている.この予想が正しければ, 疲労き裂の進展は 著しく加工硬化をうけた領域を，塑性緩和を伴いなが ら進行していく破填現象であって, Laird と Smith 


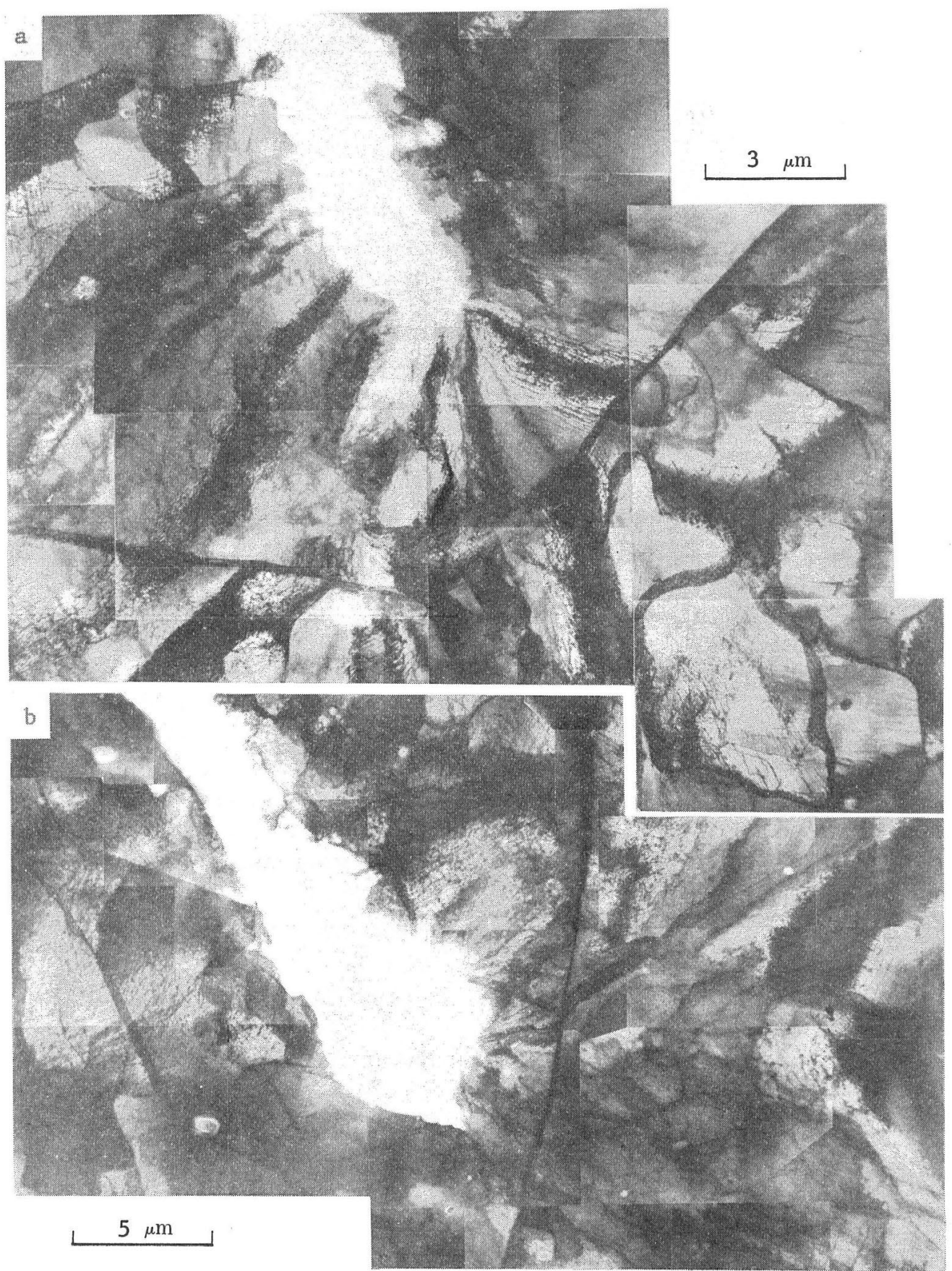

Fig. 6. Dislocation structures formed ahead of the tip of propagating crack.

提案した，い方ゆる Plastic Blunting Process が内部 組織的な立場からも理解しうるように思われる。

$$
4 \text { 結 論 }
$$

以上，ある条件でのジェット式電解研摩法により， 疲労した鉄のバルク材から，き裂を含さ薄膜試料の作 製の可能であることを示し，この試料をもってき裂先 端近傍の転位組織を $2000 \mathrm{kV}$ の超高箸圧電子顕微鏡
で観察したそその結果，次の事実が明らかになった。

（1）き裂の側面に近い領域では微細なセル組織が形 成され，それらセル内の見掛け上の転位密度はかなり 低い。また，七ルの寸法はき裂の側面からの距離に従 って大きくなるよらである。

（2）き裂の先端近傍では非常に高い密度のからみ合 った転位林が形成され，このためにセル組織は不明り 


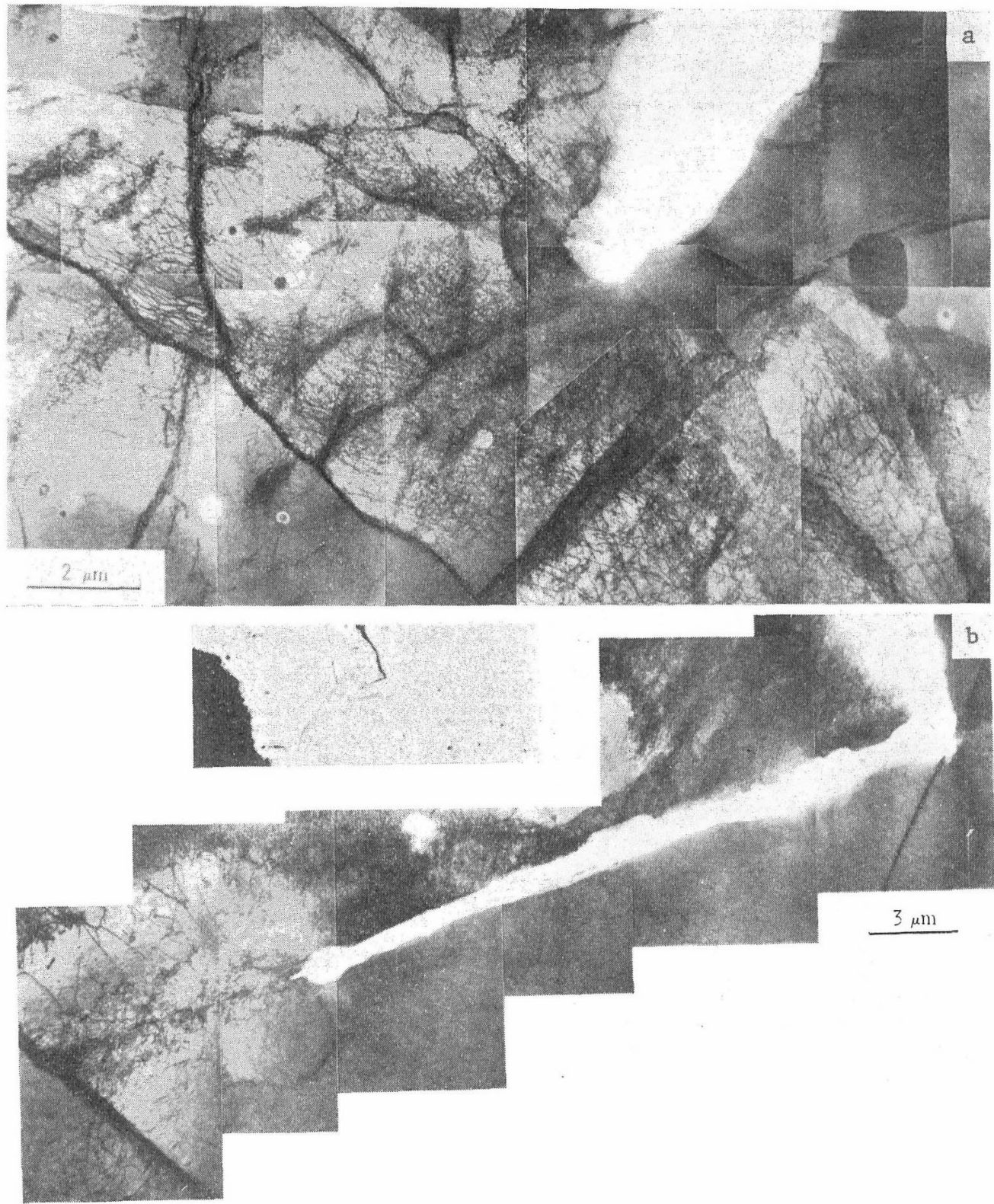

Fig. 7. Dislocation structures formed ahead of the tip of nonpropagating crack.

ょらになっている、これら転位林により，艺の䫀域は 著しく加工硬化されているるのと思われる。

（3）き裂が通過寸机ば，き裂先端近傍に形成されて

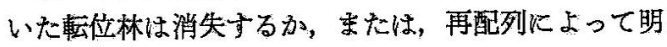
りょらなセ儿㪻を形成する。したがって，裂の通過 には，功なりの塑性緩和を伴うものと思われる。

(4) 試験片の内部で性，主き裂の先端にミクロ・ク シックやボイドは観察されなかった。 したがって、こ

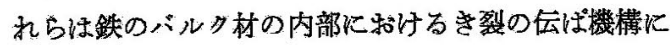
寄与していないるのと思われた。

（5）セ儿壁に沿って進行せず沉，むしろ，七儿を分
割しながら進展しているようにみ光るき裂が多く観察 された．しかし，き裂の通過烧たり転位の再配列が 起こるので，このような観察結果からきき裂の進展機構 について正しい知見は得られないように思われた。

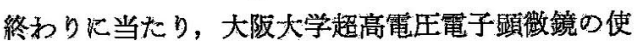
用に際し，種々の便宜を与えられた同卙徽鏡せンター

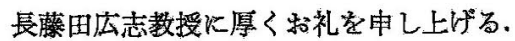

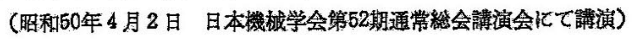

参考 文 献

1) Murr, L. E., and P. J. Smith, Trans. Metal. Soc. 

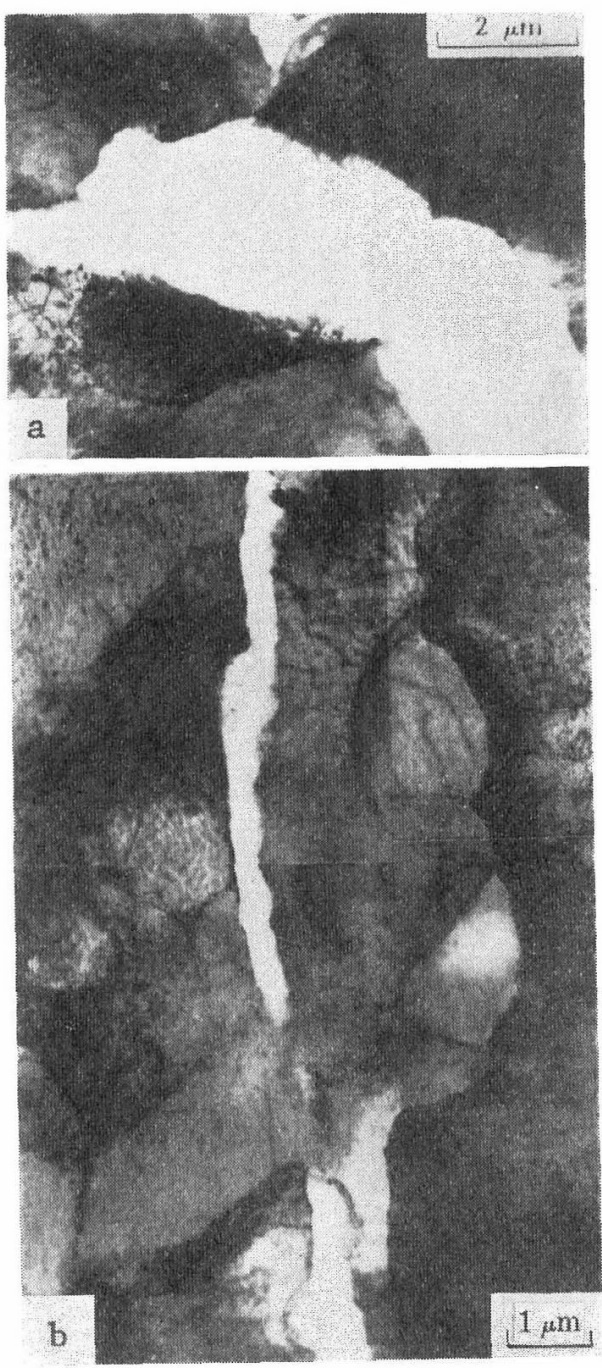

Fig. 8. The route of fatigue crack which shows propagating across cells.
AIME, 233, 755 (1965).

2）辛島誠一，及川 洪，小會议夫，金属学会誌，31，674 (1967).

3）上村正洛合政信，川辺爱昭，山田朝治，材料，24, 66 (1975).

4) Grosskreutz, J. C., and G. G. Shaw, Acta Met., 20, 523 (1972).

5) 栗谷丈夫，是枝淳尖，機械学会論文集，33，843 (1967).

6) Koterazawa, R., 1971 Inter. Conf. Mech. Behavior of Materials (Kyoto), Vol. 2, p.209.

7) Klesnil, M., and P. Lukas, Phil. Mag., 17, 1195 (1968).

8) Purcell, A.H., and J. Weertman, Met. Trans., 14, 349 (1973).

9) Thomas, G., "Transmission Electron Microscopy of Metals", p. 234 (1964) John Wiley \& Sons, Inc.

10) Grosskreutz, I. C., and P. Waldow, Acta Met., 11, 717 (1963).

11) Avery, D.H., and W. A. Backofen, "Fracture of Solid", p. 339 (1962) Interscience Publ.

12) Laird, C., and G. C. Smith, Phil. Mag., 7, 847 (1962). 